\title{
Sistem Peminjaman Sepeda Otomatis Berbasis QR-Code
}

\author{
Reinaldi Prasetya, Heru Supriyono \\ Program Studi Informatika \\ Universitas Muhammadiyah Surakarta \\ Surakarta, Indonesia \\ Email: Reiprasetya@gmail.com Heru.Supriyono@ums.ac.id
}

\begin{abstract}
Abstraksi-Saat ini sistem peminjaman sepeda yang berkembang masih menerapkan sistem peminjaman tradisional. Berdasarkan contoh studi kasus di wilayah kampus UMS, sistem peminjaman masih menggunakan sistem manual yang mengharuskan peminjam sepeda mengambil kunci sepeda pada petugas dan menuliskan data peminjam pada sebuah kertas. Sistem peminjaman ini memiliki kekurangan di antaranya adalah tingkat efisiensi yang kurang dalam pelaksanaannya. Berdasarkan studi kasus tersebut, muncul gagasan inovatif untuk membuat sebuah model simulasi sistem peminjaman sepeda otomatis menggunakan Aplikasi QR-code scanner berbasis Android sebagai medianya. Aplikasi tersebut akan digunakan untuk membaca QR-code pada sepeda. Di sisi lain, Raspberry Pi akan berkomunikasi dengan Aplikasi Android QR-code scanner dan juga digunakan sebagai controller LED (LightEmitting Diode) yang digunakan sebagai simulasi dari sistem kunci pada sepeda. Penelitian ini bertujuan untuk mempermudah dalam pendataan peminjaman sepeda dan juga meningkatkan efisiensi pengguna dalam melakukan peminjaman sepeda.
\end{abstract}

Kata Kunci-Sepeda, Internet of Things, Raspberry pi, QR-code

Abstracts-At present, the development of a bicycle lending system still applies to a traditional lending system. Based on a case study example in the UMS campus area, the lending system still uses a manual mode that requires bicycle borrowers to take bicycle keys to officers and write down borrower data on paper. This loan system has weaknesses, including a lack of efficiency in its implementation. Based on the case study, an innovative idea emerged to create a simulation model for automatic bicycle lending using the Android-based QR-Code Scanner application as a medium. This application will be used to read the QR-Code by bicycle. On the other hand, the Raspberry Pi will communicate with the Android QR-code Scanner Application and is also used as an LED (light-emitting diode) controller that is used as a critical system simulation on bicycles. This study aims to facilitate the collection of bicycle data and also increase the efficiency of users in borrowing bicycles.

Keywords-Bicycle, Internet of Things, Raspberry Pi, QR-code

\section{PENDAHULUAN}

Perkembangan teknologi di zaman globalisasi mengalami pertumbuhan yang sangat pesat. Di masa mendatang, teknologi diharapkan untuk dapat terhubung antara satu perangkat dengan perangkat lainnya dan dapat berkomunikasi secara cerdas melalui Internet sebagai media nya, hal inilah yang menjadi konsep dasar dari Internet of Things (IoT). Internet of Things (IoT) adalah paradigma komunikasi yang belakangan ini rencanakan dalam waktu dekat, di mana benda-benda yang digunakan dalam kehidupan sehari-hari akan dilengkapi dengan microcontroller, transceiver untuk komunikasi digital, dan tumpukan protokol yang akan membuat mereka untuk dapat berkomunikasi satu sama lain dan dengan pengguna [4]. Penerapan teknologi IoT sudah banyak diimplementasikan, salah satunya dalam pengembangan Smart Campus. Smart Campus adalah contoh kecil dari Smart City dan fokus pada sekolah, universitas, lembaga pemerintah, dan bangunan lainnya [1].

Pemanfaatan QR Code saat ini tidak hanya digunakan dalam aspek komersial saja, namun telah banyak digunakan dalam aspek lainnya secara luas [5]. QR-Code (Quick Response Code) adalah jenis barcode dua dimensi yang merupakan pengembangan dari barcode yang dikembangkan oleh Denso Corporation, sebuah perusahaan yang bergerak di bidang automotif di jepang. QR-code menggunakan metode pengkodean yang jauh lebih cepat dari barcode lainnya, dapat menyimpan data dalam jumlah besar dan dapat digunakan dimana saja [3]. Raspberry Pi (Rpi) adalah sebuah komputer dengan papan sirkuit tunggal berukuran kecil yang dapat digunakan untuk menjalankan program seperti komputer pada umumnya. Raspberry Pi dikontrol oleh versi modifikasi dari Debian Linux yang di optimalkan untuk arsitektur ARM [2]. Raspberry Pi dapat digunakan sebagai Server dan Embedded Controller perangkat lain melalui pin GPIO yang terhubung dengannya.

Saat ini sistem peminjaman sepeda yang berkembang masih menerapkan sistem peminjaman tradisional. Berdasarkan contoh studi kasus di wilayah kampus UMS, sistem peminjaman masih menggunakan sistem manual yang mengharuskan peminjam sepeda mengambil kunci sepeda pada petugas dan menuliskan data peminjam pada sebuah kertas. sistem peminjaman ini memiliki kekurangan yaitu adalah tingkat efisiensi yang kurang dalam pelaksanaannya. Berdasarkan studi kasus tersebut, muncul gagasan inovatif penulis untuk membuat sebuah model Sistem peminjaman sepeda otomatis menggunakan Aplikasi QR-code Scanner berbasis Android sebagai media- 
nya. Aplikasi tersebut akan digunakan untuk membaca QRcode pada sepeda yang kemudian data tersebut akan diolah di WebServer. Di sisi lain, Raspberry Pi digunakan sebagai controller LED (Light-Emitting Diode) yang digunakan sebagai simulasi dari sistem kunci pada sepeda. Penelitian ini bertujuan untuk mempermudah pendataan peminjaman sepeda dan juga meningkatkan efisiensi pengguna dalam melakukan peminjaman dan mempermudah pendataan pada peminjaman.

\section{METODE PENELITIAN}

Penelitian ini menggunakan metode System Development Life Cycle dengan pendekatan model Waterfall dalam membangun sistem peminjaman sepeda otomatis berbasis QR-code. SDLC merupakan pendekatan yang digunakan dalam Industri Software, yang digunakan untuk pengembangan berbagai ukuran skala proyek, dari Proyek skala kecil hingga proyek skala besar.

\section{A. Analisa Kebutuhan}

Pada penelitian ini Hardware yang digunakan yaitu Raspberry Pi 3 model B plus sebagai Controller, Daya pada Raspberry Pi menggunakan Adapter dengan tegangan 5V/3A, MicroSD16 GB sebagai Penyimpanan Raspberry Pi, kabel LAN sebagai penghubung Raspberry Pi ke internet, kabel jumper sebagai penghubung GPIO Raspberry Pi dengan breadboard, Resistor 100 Ohm Watt dan Lampu LED yang digunakan sebagai simulasi dari sistem kunci sepeda.

Perangkat Lunak yang digunakan, Raspberry Pi yang digunakan sebagai Server menggunakan Raspbian sebagai Sistem Operasi. Perangkat Lunak yang digunakan pada server adalah Hypertext Preprocessor (PHP) yang digunakan sebagai pengembangan Website dan MySql sebagai pengolah basis data, dan Bahasa Pemrograman Python 3.7.2 yang digunakan untuk menerima Socket Server yang berfungsi sebagai penerima Output dari pengguna serta controller Lampu LED. Android Studio digunakan untuk merancang aplikasi QR code berbasis android serta sublime text yang digunakan sebagai text editor dalam pembuatan website.

\section{B. Perancangan Sistem}

Pada bagian ini akan menjelaskan mengenai Usecase Diagram, Activity Diagram, dan Rancangan tampilan sistem yang akan dibangun. Use Case Diagram pada Gambar 1 menggambarkan secara ringkas siapa yang menjalankan sistem dan tindakan apa saja yang dapat dilakukan oleh pengguna sistem. Dalam sistem ini, staf dapat memperbaharui dan verifikasi akun dari pengguna, melakukan perubahan data pada Database serta dapat melakukan memonitor peminjaman sepeda melalui Website. Di sisi lain, pengguna yang telah Login dan akun nya sudah di verifikasi dapat melakukan pemindai terhadap QRcode yang terdapat pada sepeda yang ingin dipinjam. Pengguna juga dapat melihat daftar sepeda yang tersedia melalui Aplikasi Android.

Berdasarkan pada Gambar 2, Activity Diagram memberikan gambaran proses yang berlangsung saat User melakukan proses peminjaman sepeda. Pengguna memulai proses dengan login pada sistem yang tersedia. Setelah pengguna berhasil Login

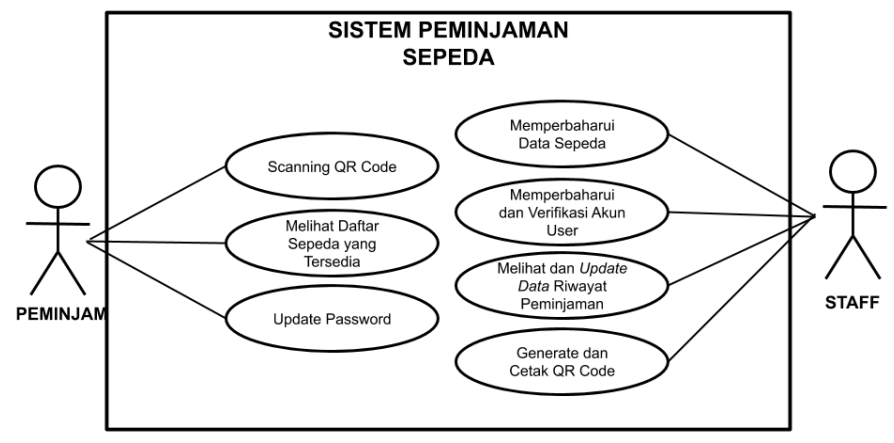

Gambar 1. Use Case Diagram Sistem Peminjaman Sepeda

aplikasi dan status Akun dari pengguna sudah ter verifikasi, User dapat membuka QR-code Scanner yang akan digunakan untuk membaca QR-code yang terdapat pada sepeda.

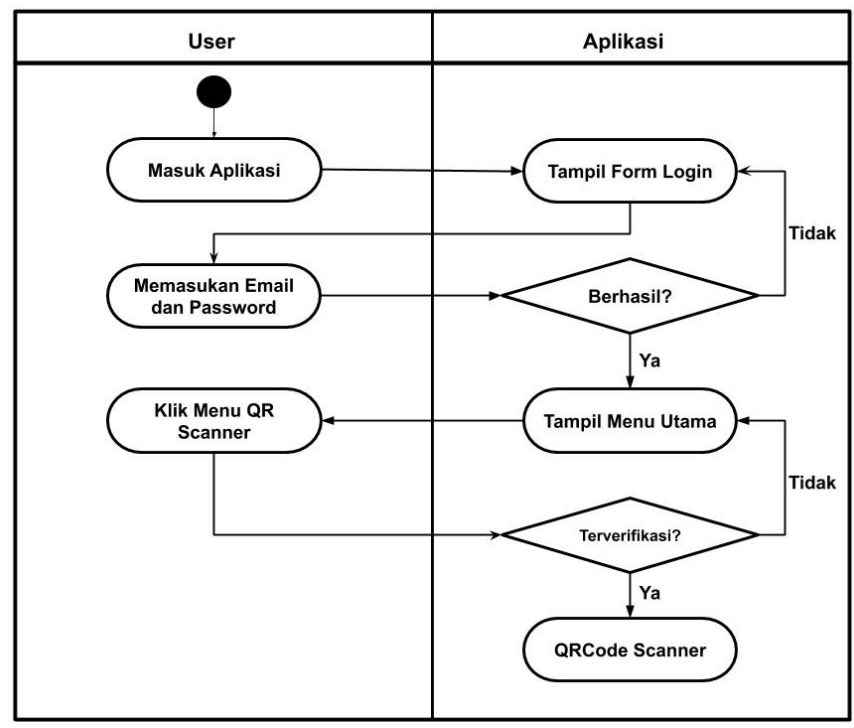

Gambar 2. Activity Diagram User Sistem Peminjaman Sepeda

\section{Rancangan Tampilan Aplikasi Android}

Pada tahap ini akan menampilkan rancangan tampilan aplikasi android yang akan digunakan sebagai acuan dalam pembuatan aplikasi yang akan dibangun. Rancangan dapat dilihat pada gambar 3 .

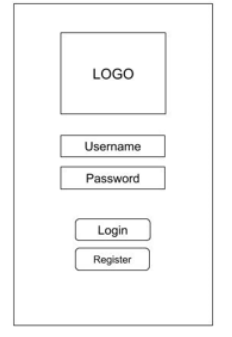

a. Halaman Login

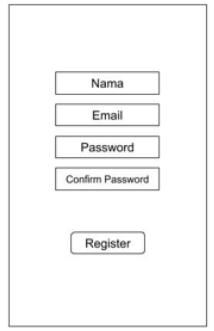

b. Halaman Register

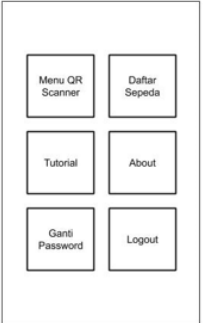

c. Menu Utama

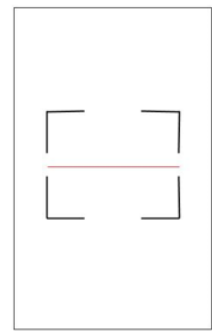

d. Menu QR Scanner
Gambar 3. Rancangan Tampilan Aplikasi Android 


\section{Implementasi Sistem}

Sistem akan dibangun berdasarkan analisis kebutuhan dan perancangan yang sudah ditetapkan sebelumnya. Implementasi sistem peminjaman sepeda otomatis akan dibangun menggunakan bahasa pemrograman Java untuk aplikasi android, Bahasa pemrograman Python 3.8.2 pada Raspberry Pi sebagai Socket Server dan Controller LED, MySQL yang digunakan sebagai pengolah basis data, dan bahasa pemrograman Hypertext Preprocessor (PHP) untuk membangun sistem memonitor peminjaman berbasis web. Pada perancangan Perangkat Keras, Sistem kunci pada sistem ini akan di simulasi menggunakan lampu LED di Breadboard yang akan di kontrol oleh Raspberry Pi.

\section{E. Pengujian Sistem}

Pengujian pada sistem Peminjaman Sepeda yang telah dibangun menggunakan metode Black Box. Pengujian dilakukan pada fungsi-fungsi dari sistem untuk mengetahui apakah sistem telah dapat berjalan dengan baik

\section{HASIL DAN PEMBAHASAN}

\section{A. Hasil Tampilan Aplikasi Android}

Aplikasi Android QR-code Scanner ini tujukan untuk pengguna aplikasi yang ingin melakukan peminjam sepeda. User yang sudah terdaftar dapat login ke aplikasi dengan melakukan pengisian form Email dan Password untuk masuk ke halaman utama aplikasi. User yang belum terdaftar dapat melakukan pendaftaran dengan cara menekan tulisan pendaftaran dibawah Form Login untuk masuk ke halaman Pendaftaran. Akun baru yang terdaftar akan berstatus belum ter verifikasi, untuk melakukan verifikasi, User harus menemui staf dengan membawa kartu identitas diri. Informasi yang terdapat pada kartu identitas diri akan di input oleh staf ke Database User melalui Website. User yang telah melakukan pendaftaran dan telah melakukan Login akan masuk ke halaman utama aplikasi. Di Halaman Utama ini terdapat beberapa menu pilihan yang dapat digunakan untuk masuk ke halaman lainnya. menu daftar sepeda yang digunakan untuk melihat daftar sepeda yang tersedia. Tampilan dapat dilihat pada gambar 4 .

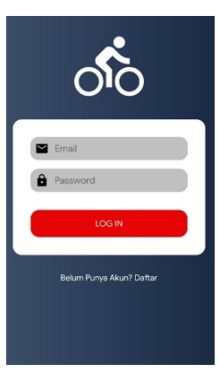

a. Login

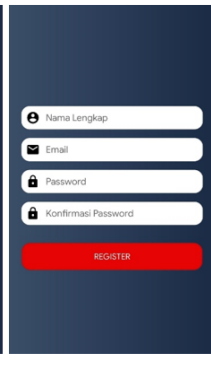

b. Register

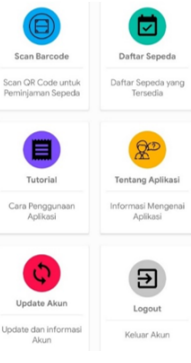

c. Menu Utama

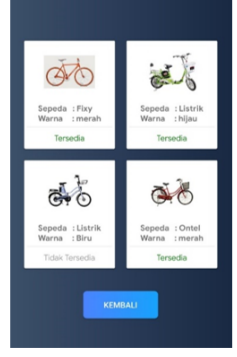

d. Menu Daftar Sepeda
Gambar 4. Tampilan Login, Register, menu utama Aplikasi dan Menu Daftar Sepeda

Menu Update Akun yang digunakan untuk melihat status akun dan melakukan update password, Menu Tutorial yang berisi informasi dalam alur dan cara penggunaan aplikasi, dan menu Scan Barcode yang digunakan untuk melakukan Scanning QR-code yang terdapat pada kunci sepeda. Penggunaan menu QR Scanner hanya bisa dilakukan pada kondisi tertentu, yaitu status akun user sudah ter verifikasi, akun user tidak memiliki denda peminjaman, dan peminjaman dilakukan pada waktu yang ditentukan. Setelah User berhasil masuk ke menu QR Scanner dan mengarahkan QR Scanner untuk membaca QR-code yang terdapat pada sistem kunci sepeda, aplikasi akan mengarahkan ke halaman hasil untuk melakukan pengecekan dan pengelolaan terhadap hasil QR-code yang dibaca, jika semua kondisi terpenuhi, Aplikasi Android ini akan mengirimkan perintah untuk membuka kunci melalui Socket Communication kepada Raspberry Pi yang berfungsi sebagai Socket Server dan Controller dari lampu LED yang disimulasikan sebagai sistem kunci. Tampilan dari Menu QR Scanner dan Hasil dapat dilihat pada gambar 8.Tampilan dari tiap Menu dapat dilihat pada gambar 5 .

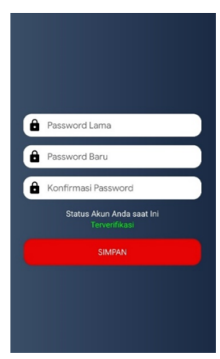

a. Menu Update Akun

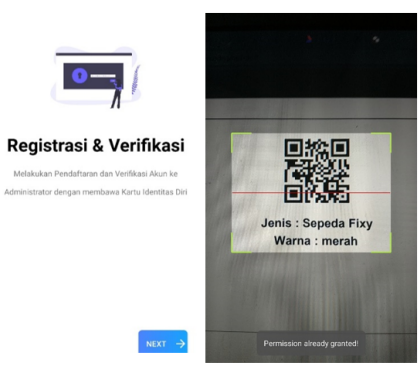

c. Menu $Q R$ Scarmer

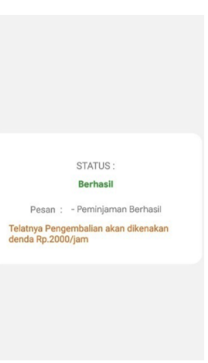

d. Menu Hasil
Gambar 5. Tampilan dari Menu Aplikasi

\section{B. Hasil Tampilan Website}

Hasil tampilan Website ini akan digunakan oleh staf dalam kegiatan memonitor dan berubah atau menambahkan data pada database Sistem. Website ini mengharuskan staf untuk login sebelum masuk ke dashboard website. Tampilan Login Website dapat dilihat pada Gambar 6.

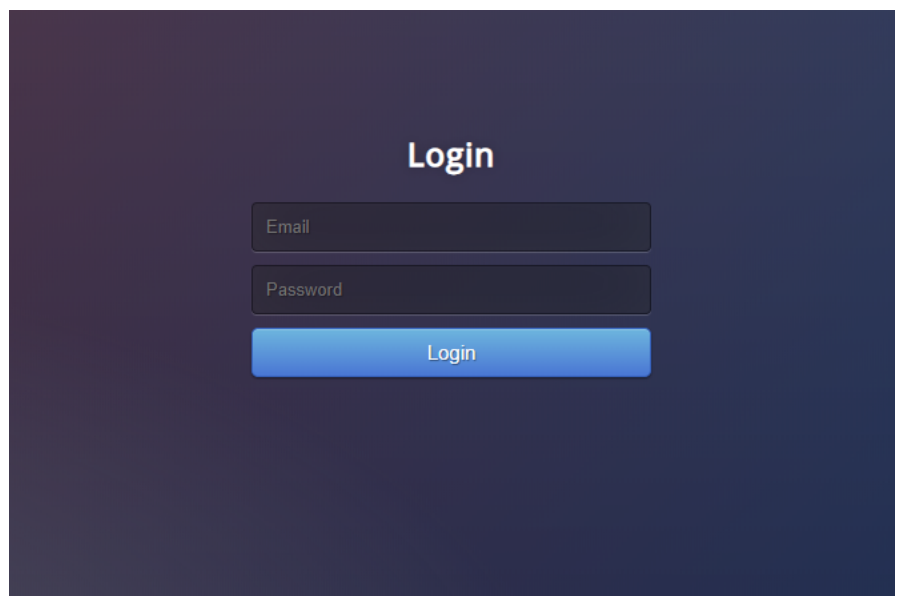

Gambar 6. Tampilan halaman Login dari Website

Staf yang berhasil login akan masuk ke halaman dashboa$r d$. Halaman dashboard sendiri memiliki beberapa sub-menu yang akan mengarahkan ke halaman pengelolaan. Tampilan dashboard dapat dilihat pada Gambar 7.

Submenu daftar user akan mengarahkan ke halaman yang menampilkan daftar user yang terdaftar. Di halaman ini staf 
Tabel I. Pengujian Jarak Pengujian QR-code

\begin{tabular}{|c|c|c|c|c|}
\hline No & Pengujian & Test Case & Harapan & Hasil \\
\hline 1 & User Register dan Login & User melakukan Register dan Login & $\begin{array}{l}\text { User berhasil melakukan Register dan Login, lalu masuk } \\
\text { ke Menu Utama }\end{array}$ & Sesuai \\
\hline 2 & User Ganti Password & User melakukan Update Password & $\begin{array}{l}\text { User berhasil mengganti Password pada Akun yang di- } \\
\text { miliki melalui menu Update Akun. }\end{array}$ & Sesuai \\
\hline 3 & User Cek Daftar Sepeda & User masuk ke Menu Daftar Sepeda & $\begin{array}{l}\text { User dapat melihat daftar sepeda yang tersedia secara } \\
\text { Real Time }\end{array}$ & Sesuai \\
\hline 4 & $\begin{array}{l}\text { User Melakukan Peminjaman Dan } \\
\text { Pengembalian Sepeda }\end{array}$ & $\begin{array}{l}\text { User Masuk ke Menu QR Scanner dan } \\
\text { Melakukan Pembacaan pada QR-code }\end{array}$ & $\begin{array}{l}\text { User yang terverifikasi dapat melakukan peminjaman dan } \\
\text { pengembalian sepeda melalui Menu QR Scanner dengan } \\
\text { membaca QR-code pada kunci sepeda }\end{array}$ & Sesuai \\
\hline 5 & Penutupan Menu QR Scanner & $\begin{array}{l}\text { User Mencoba Masuk ke Menu QR } \\
\text { Scanner }\end{array}$ & $\begin{array}{l}\text { Menu QR Scanner tidak bisa diakses jika Akun User } \\
\text { belum Terverifikasi, di luar jam peminjaman, dan User } \\
\text { memiliki denda }\end{array}$ & Sesuai \\
\hline 6 & Admin Login ke Website & Admin melakukan Login ke Website & $\begin{array}{l}\text { Admin yang terdaftar dapat Login ke Website dan masuk } \\
\text { ke Dashboard }\end{array}$ & Sesuai \\
\hline 7 & $\begin{array}{l}\text { Admin mengakses Submenu Daftar } \\
\text { Admin dan Daftar User }\end{array}$ & $\begin{array}{l}\text { Admin mengakses submenu Daftar } \\
\text { Users dan Daftar Admin dan juga dapat } \\
\text { mengakses semua fungsi pada kedua } \\
\text { submenu tersebut }\end{array}$ & $\begin{array}{l}\text { Admin masuk ke halaman daftar User dan daftar Admin. } \\
\text { melihat daftar User dan Admin serta dapat melakukan } \\
\text { Penambahan Admin dan Users, memverifikasi akun User, } \\
\text { Update informasi User, dan Delete akun User }\end{array}$ & Sesuai \\
\hline 8 & $\begin{array}{l}\text { Admin mengakses Submenu Daftar } \\
\text { Sepeda }\end{array}$ & $\begin{array}{l}\text { Admin mengakses submenu daftar se- } \\
\text { peda dan dapat mengakses semua fung- } \\
\text { si pada submenu tersebut }\end{array}$ & $\begin{array}{l}\text { Admin Masuk ke halaman daftar sepeda dan dapat mela- } \\
\text { kukan beberapa fungsi seperti Update informasi Sepeda, } \\
\text { generate QR-code, dan mencetak QR-code }\end{array}$ & Sesuai \\
\hline 9 & $\begin{array}{l}\text { Admin mengakses Submenu Pe- } \\
\text { minjaman dan Denda Peminjaman }\end{array}$ & $\begin{array}{l}\text { Admin mengakses submenu peminjam- } \\
\text { an dan denda peminjaman, serta dapat } \\
\text { mengakses semua fungsi pada submenu } \\
\text { tersebut }\end{array}$ & $\begin{array}{l}\text { Admin masuk ke halaman daftar peminjaman dan denda } \\
\text { peminjaman, serta dapat mengakses fungsi fungsi seperti } \\
\text { mengubah data peminjaman dan penerimaan pembayaran } \\
\text { denda. }\end{array}$ & Sesuai \\
\hline 10 & $\begin{array}{l}\text { Raspberry Pi menerima perintah } \\
\text { dan menghidupkan lampu }\end{array}$ & $\begin{array}{l}\text { Raspberry Pi menerima perintah untuk } \\
\text { menghidupkan lampu melalui Socket } \\
\text { Communication }\end{array}$ & $\begin{array}{l}\text { Raspberry Pi yang berfungsi sebagai Socket Server me- } \\
\text { nerima perintah untuk menghidupkan lampu LED yang } \\
\text { dikirimkan Aplikasi Android }\end{array}$ & Sesuai \\
\hline
\end{tabular}
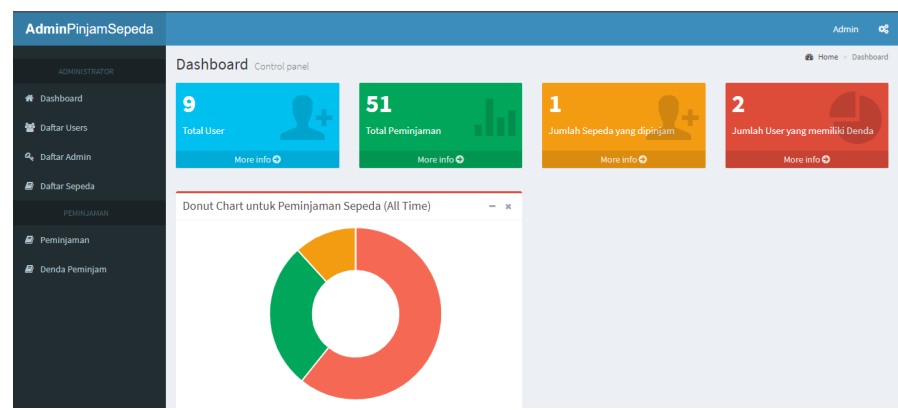

Gambar 7. Tampilan Halaman Dashboard Website

dapat melakukan penambahan user baru, verifikasi akun user, update dan delete pada akun user, dan melihat daftar riwayat peminjaman dari masing-masing user. Tampilan dapat dilihat pada Gambar 8.

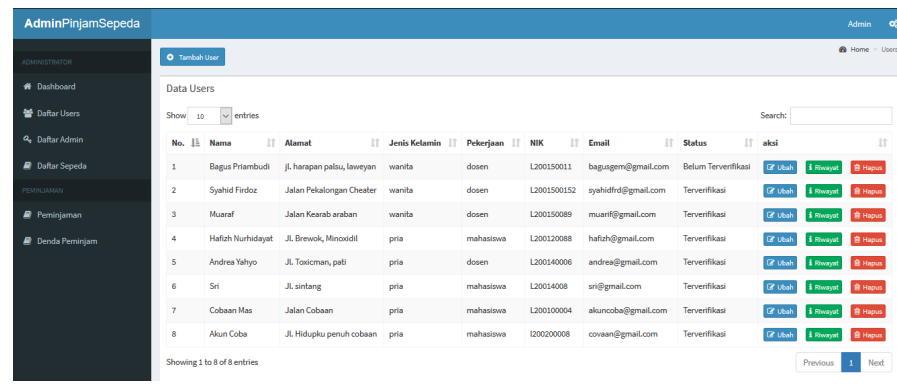

Gambar 8. Tampilan Submenu Daftar Users

Pada submenu daftar admin akan mengarahkan ke halaman yang menampilkan daftar admin yang terdaftar. admin yang saat ini dapat mendaftarkan admin baru untuk mempermudah kegiatan memonitor pada sistem. Tampilan dari submenu daftar admin dapat dilihat pada Gambar 9.

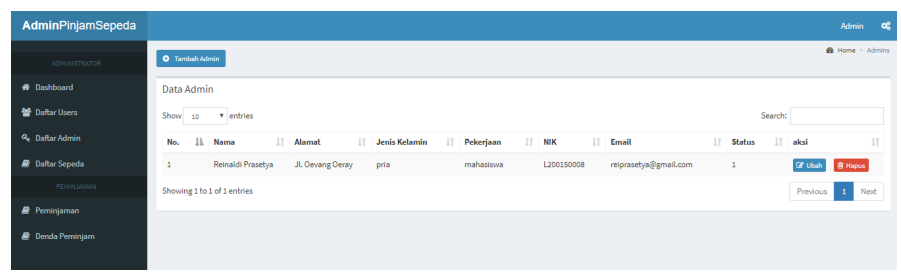

Gambar 9. Tampilan Submenu Daftar Admin

Submenu daftar sepeda akan mengarah ke halaman pengelolaan data sepeda. Di halaman ini admin dapat melakukan perubahan informasi pada sepeda, Generate CR Code baru, pencetakan QR-code, dan melihat riwayat peminjaman dari masing-masing sepeda. Untuk tampilan submenu daftar sepeda dapat dilihat pada Gambar 10.

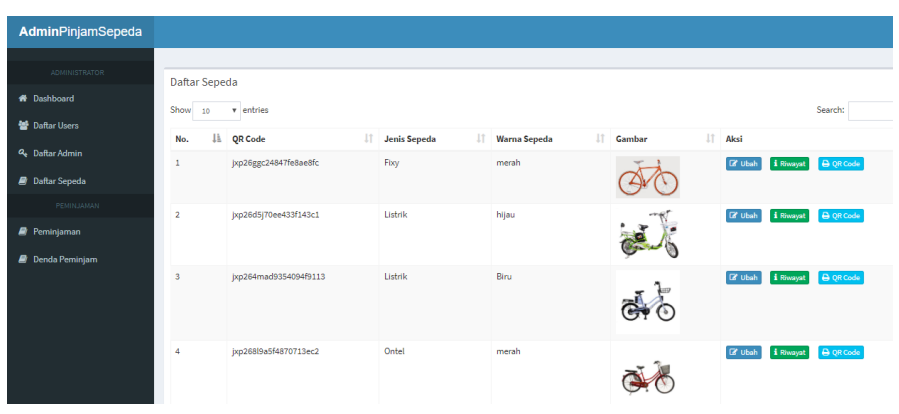

Gambar 10. Tampilan Submenu Daftar Sepeda

Submenu peminjaman akan menampilkan daftar riwayat peminjaman yang berisi informasi mengenai peminjaman yang dilakukan oleh user. Admin dapat melakukan perubahan data pada bagian-bagian tertentu dari data peminjaman. Tampilan submenu peminjaman dapat dilihat pada Gambar 11. 


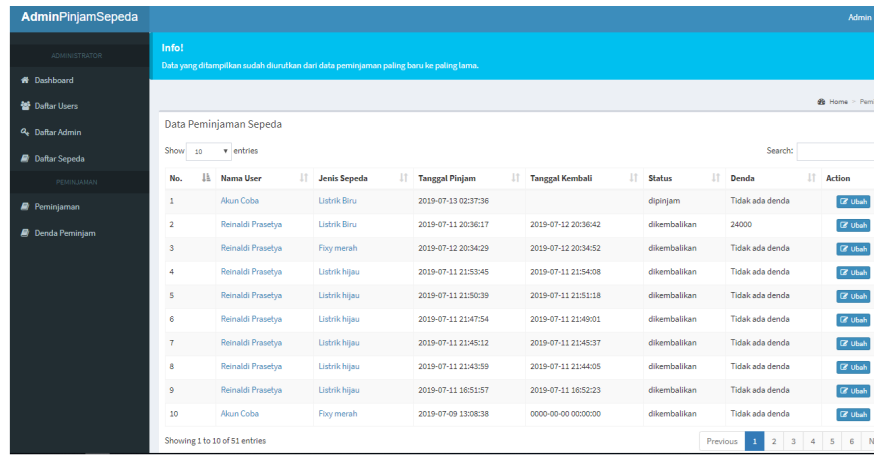

Gambar 11. Tampilan Submenu Peminjaman

Pada Submenu denda peminjaman akan menampilkan daftar user yang memiliki denda pada peminjaman terakhir dari user yang bersangkutan. Di halaman ini admin dapat menghapus data denda yang telah di bayarkan oleh user. Tampilan submenu denda peminjaman dapat dilihat pada Gambar 12.

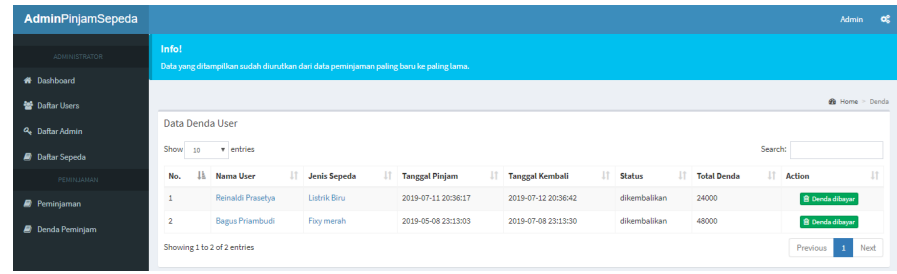

Gambar 12. Tampilan Submenu denda peminjaman

\section{Hasil Tampilan dari Simulasi Sistem Kunci}

Simulasi dari sistem kunci yang digunakan menggunakan lampu LED yang terhubung ke papan Projek Breadboard yang terhubung dengan resistor dan GPIO dari Raspberry Pi. Tampilan dari simulasi sistem kunci dapat dilihat pada Gambar 13.

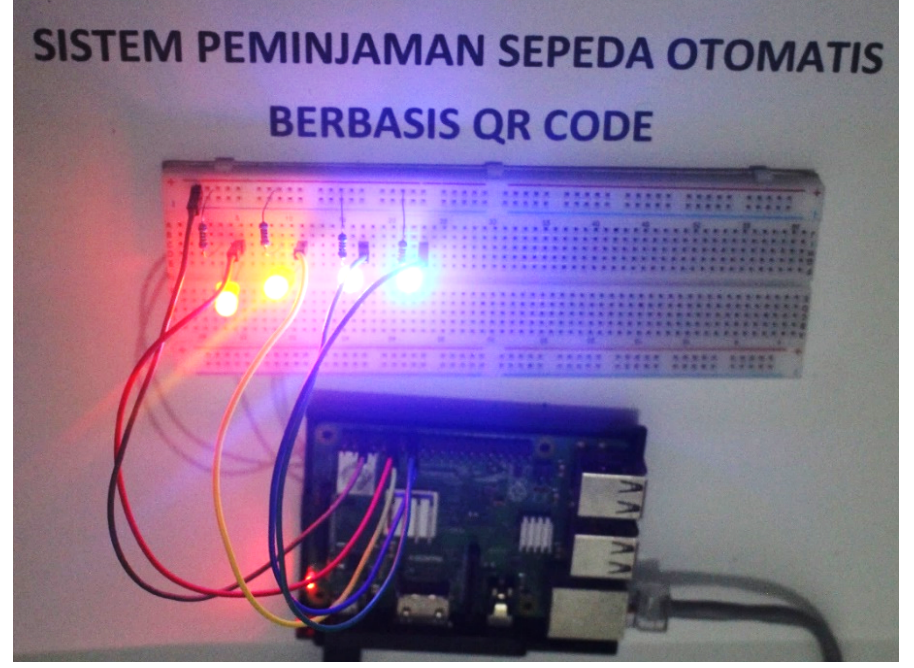

Gambar 13. Tampilan dari Simulasi Kunci

\section{Pengujian Pengujian Black-Box}

Pengujian Blackbox dilakukan untuk mengetahui apakah sistem dapat berjalan sesuai dengan yang diharapkan seperti terlihat dalam Tabel I.

\section{E. Pengujian pada Smartphone}

Pengujian ini dilakukan untuk mengetahui apakah aplikasi dapat berjalan pada beberapa Smartphone yang berbeda. Hasil pengujian dengan beberapa Smartphone berbasis android terdapat pada Tabel II.

Tabel II. Hasil Pengujian di Smartphone

\begin{tabular}{llll}
\hline No & Merek Smartphone & Spesifikasi Smartphone & Keterangan \\
\hline 1 & Xiaomi Redmi Note 5 & Android 9.0, Ram 4gb/64gb & Berfungsi baik \\
2 & Xiaomi Redmi Note 4x & Android 7.0, Ram 3gb/32gb & Berfungsi baik \\
3 & Asus Max Pro M1 & Android 9.0, Ram 3gb/32gb & Berfungsi baik \\
4 & Oppo F1 Plus & Android 5.1, Ram 4gb/64gb & Berfungsi baik \\
\hline
\end{tabular}

\section{F. Uji Coba QR-code}

Pengujian QR-code bertujuan untuk mengetahui apakah QR-code dapat dibaca tanpa adanya masalah. Pengujian pertama adalah pengujian tingkat cahaya pada QR-code, hasil di tunjukan pada Tabel III.

Tabel III. Pengujian Jarak Pengujian QR-code

\begin{tabular}{lll}
\hline No & Tingkat Cahaya & Keterangan \\
\hline 1 & Sangat Terang & Terbaca \\
2 & Terang & Terbaca \\
3 & Redup & Terbaca \\
4 & Gelap & Terbaca \\
5 & Sangat Gelap & Gagal Terbaca \\
\hline
\end{tabular}

Pengujian kedua adalah Pengujian dilakukan dengan melakukan coretan pada QR-code dengan menggunakan pena. Coretan pada QR-code dilakukan dengan beberapa tingkatan hingga 15 coretan, dengan hasil QR Scanner tetap bisa membaca QR-code dengan baik.

Pengujian Ketiga adalah Pengujian dilakukan untuk mengetahui jarak yang dapat dibaca oleh QR Scanner. Pengujian dilakukan dengan melakukan pembacaan QR-code pada jarak dengan beberapa tingkatan hingga $50 \mathrm{~cm}$, dengan hasil QR-code tetap bisa terbaca oleh QR Scanner hingga jarak $50 \mathrm{~cm}$.

Kesimpulan dari pengujian QR-code yang telah dilakukan yaitu pengujian tingkat cahaya pada QR-code menunjukkan bahwa QR-code hanya tidak bisa dibaca pada kondisi pencahayaan yang sangat gelap. Selanjutnya pada pengujian coretan pada QR-code menunjukkan bahwa QR-code tetap dapat dibaca oleh QR Scanner hingga 15 Coretan. Untuk Pengujian jarak QR-code, QR Scanner dapat membaca QR-code hingga jarak $50 \mathrm{~cm}$.

\section{G. Uji Coba QR-code}

Pengujian kuesioner ini mendapat responden dengan jumlah 25 orang dan 1 orang admin. Sebelum responden mengisi kuesioner sebagian sudah menonton display dari video yang telah diunggah di youtube dan sebagian lainnya sudah mencoba aplikasi secara langsung. Hasil kuesioner terdapat pada Tabel 
IV dan Tabel V. Hasil yang telah didapat akan dihitung dengan rumus Persamaan 1.

$$
\text { Hasil }=\frac{\sum \text { Skor }}{\text { Skor Maksimal }} \times 100 \%
$$

Skor Maksimal didapatkan dengan menggunakan perhitungan dari rumus Persamaan 2.

$$
\text { Skor Maksimal }=\sum \text { Responden } \times 5
$$

Sebagai misal bila Responden $=25$ maka Skor Maksimal adalah $25 \times 5=125$.

\begin{tabular}{|c|c|c|c|c|c|c|c|c|}
\hline \multirow{2}{*}{ No } & \multirow{2}{*}{ Pertanyaan } & \multicolumn{5}{|c|}{ Jawaban } & \multirow{2}{*}{ Skor } & \multirow{2}{*}{ Nilai (\%) } \\
\hline & & SS & S & $\mathrm{N}$ & TS & STS & & \\
\hline 1 & $\mathrm{P} 1$ & 22 & 3 & 0 & 0 & 0 & 122 & 97.60 \\
\hline 2 & $\mathrm{P} 2$ & 24 & 1 & 0 & 0 & 0 & 124 & 99.20 \\
\hline 3 & $\mathrm{P} 3$ & 13 & 10 & 2 & 0 & 0 & 111 & 88.80 \\
\hline 4 & $\mathrm{P} 4$ & 16 & 9 & 0 & 0 & 0 & 116 & 92.80 \\
\hline 5 & P5 & 19 & 6 & 0 & 0 & 0 & 119 & 95.20 \\
\hline 6 & P6 & 22 & 3 & 0 & 0 & 0 & 122 & 97.60 \\
\hline 7 & P7 & 21 & 4 & 0 & 0 & 0 & 121 & 96.80 \\
\hline \multicolumn{8}{|c|}{ Total Rata-rata Persentase } & $95.43 \%$ \\
\hline
\end{tabular}

Tabel IV. Hasil Kuesioner Pengguna

Keterangan dari kode tabel adalah sebagai berikut P1=Sistem mudah dipahami dan di akses. P2=Informasi yang ditampilkan mudah dipahami. P3=Tampilan aplikasi menarik tidak membosankan. $\mathrm{P} 4=$ Semua fungsi dapat berjalan dengan baik. P5=Sistem mempermudah dalam peminjaman sepeda. P6=Sistem dapat menghemat waktu peminjaman sepeda. P7=Sistem Layak untuk di implementasikan. SS=Sangat Setuju. $\mathrm{S}=$ Setuju. N=Netral. TS=Tidak Setuju. Terakhir, STS=Sangat Tidak Setuju.

\begin{tabular}{|c|c|c|c|c|c|c|c|c|}
\hline \multirow{2}{*}{ No } & \multirow{2}{*}{ Pertanyaan } & \multicolumn{5}{|c|}{ Jawaban } & \multirow{2}{*}{ Skor } & \multirow{2}{*}{ Nilai $(\%)$} \\
\hline & & SS & $\mathrm{S}$ & $\mathrm{N}$ & $\mathrm{TS}$ & STS & & \\
\hline 1 & $\mathrm{P} 1$ & 1 & 0 & 0 & 0 & 0 & 5 & 100.00 \\
\hline 2 & $\mathrm{P} 2$ & 1 & 0 & 0 & 0 & 0 & 5 & 100.00 \\
\hline 3 & P3 & 1 & 0 & 0 & 0 & 0 & 5 & 100.00 \\
\hline 4 & $\mathrm{P} 4$ & 0 & 1 & 0 & 0 & 0 & 4 & 80.00 \\
\hline 5 & P5 & 0 & 1 & 0 & 0 & 0 & 4 & 80.00 \\
\hline 6 & P6 & 1 & 0 & 0 & 0 & 0 & 5 & 100.00 \\
\hline 7 & $\mathrm{P} 7$ & 1 & 0 & 0 & 0 & 0 & 5 & 100.00 \\
\hline \multicolumn{8}{|c|}{ Total Rata-rata Persentase } & $94.29 \%$ \\
\hline
\end{tabular}

Tabel V. Hasil Kuesioner Admin
Berdasarkan hasil pengujian kuesioner pengguna diperoleh rata-rata nilai sebesar 95,43\% dan kuesioner Admin sebesar 94,29\% yang dapat disimpulkan bahwa sistem berada pada kategori baik dan dapat diterima oleh pengguna dan juga Admin.

\section{KESIMPULAN}

Sistem Peminjaman Sepeda Otomatis berbasis QR-code dibangun mempermudah kegiatan peminjaman sepeda dan pendataan dari sistem peminjaman ini. Dari Perancangan Sistem yang dibuat, berdasarkan pengujian dengan metode Blackbox, dapat ditarik kesimpulan bahwa fungsi-fungsi pada sistem dapat berjalan dengan baik dan sesuai dengan perencanaan. Pengujian yang dilakukan kepada responden sebanyak 25 User yang menunjukkan hasil $95,43 \%$ dan $94,29 \%$ dari 1 orang admin bahwa sistem yang dibangun berada pada kategori baik dan dapat diterima oleh pengguna dari sistem.

\section{Daftar Pustaka}

[1] Angulo-Esguerra, D., Villate-Barrera, C., Giral, W., Florez, H. C., ZonaOrtiz, A. T., \& Diaz-Sanchez, F. (2017). Parkurbike: An IoT-based system for bike parking occupation checking. In 2017 IEEE Colombian Conference on Communications and Computing, COLCOM 2017 - Proceedings. https://doi.org/10.1109/ColComCon.2017.8088201

[2] Pavithra, D., \& Balakrishnan, R. (2015). IoT based memonitor and control system for home automation. In Global Conference on Communication Technologies, GCCT 2015. https://doi.org/10.1109/GCCT.2015.7342646

[3] Rahaman, W. (2016). Enhancing Library Services Using Barcode, Qr Code And Rfid Technology: A Case Study In Central Library National Institute Of Technology, Rourkela. International Journal of Digital Library Services IJODLS - Geetanjali Research Publication.

[4] Zanella, A., Bui, N., Castellani, A., Vangelista, L., \& Zorzi, M. (2014). Internet of things for smart cities. IEEE Internet of Things Journal. https://doi.org/10.1109/JIOT.2014.2306328

[5] Yusuf Egwoh, A., \& Francisca Nonyelum, O. (2017). A Software System Development Life Cycle Model For Improved Students Communication And Collaboration. International Journal of Computer Science \& Engineering Survey (IJCSES). https://doi.org/10.5121/ijcses.2017.8401 